\title{
Evapotranspiration and Yield of Eggplant under Salinity and Water Deficit: A Comparison between Greenhouse and Outdoor Cultivation
}

\author{
Ali Asghar Ghaemi ${ }^{1} \&$ Mohammad Rafie Rafiee ${ }^{2}$ \\ ${ }^{1}$ Associate Professor, Water Engr. Dept. College of Agric. Shiraz University, Shiraz, I.R. Iran \\ ${ }^{2}$ Assistant Professor, Irrigation Dept. Jahrom Univercity, Jahrom , I.R. Iran \\ Correspondence: Ali Asghar Ghaemi, Water Engr. Dept. College of Agric. Shiraz University, Shiraz, I.R. Iran. \\ Tel: 0917-111-5795. E-mail: ghaemi@shirazu.ac.ir/ghaemiali@yahoo.com
}

Received: May 27, 2016

doi:10.5539/mas.v10n11p8
Accepted: June 8, 2016

URL: http://dx.doi.org/10.5539/mas.v10n11p8

\begin{abstract}
Cultivation environment can be effective on the degree of limitations in crop evapotranspiration and yield, as a result of water shortage and salinity. The purpose of this study was to determine and compare the impact of different irrigation regimes (daily, weekly and every two weeks) combined with different water salinities $(0.8$, 2.5, 5.0 and, $7.0 \mathrm{dS} \mathrm{m}^{-1}$ ) on eggplant yield $(\mathrm{Y})$ and evapotranspiration (ETc) in outdoor and greenhouse cultivation. Daily ETc values were measured by diurnal weighting of microlysimeters throughout the growing season (from May 19th to September 5th, 2012 and June 1st to September 22nd, 2013) placed in a plastic greenhouse and outdoor basins. Measurements showed apparent variations between different irrigation regimes $\times$ water salinity treatments, during the early growing season in both years. Both water deficit and salinity factors had significant effects on ETc, ECe, Y, fruit diameter and shoot dry weight in both environments. The applicability of Doorenbos-Kassam linear crop-water production function along with Maas-Hoffman salt tolerance model was investigated in the greenhouse and outdoor conditions. The Ky coefficient obtained for outdoor and greenhouse eggplants treatments were 0.97 and 1.03 in the first year and 0.91 and 0.93 in the second year, respectively. Higher sensitivity of greenhouse eggplants to salinity was later demonstrated for both years, obtaining higher values of $\mathrm{b}$ and lower values of $\mathrm{ECe}_{\text {threshold }}$ in the greenhouse eggplants.
\end{abstract}

Keywords: evapotranspiration, water deficit, salinity, greenhouse

\section{Introduction}

One necessity for efficient irrigation, with minimum percolation, runoff losses and environmental pollution, is the knowledge of consumption use of crops or their evapotranspiration. Yet several methods for calculating $\mathrm{ET}_{\mathrm{c}}$ have been used and evaluated for outdoor cultivation while the precision of such methods in greenhouses are not that perspicuous.

Soil water shortage and salinity lowers the potential energy of water and bounds it by capillary and absorptive forces to the soil matrix. This may result in scanty plant growth, reduction of water uptake and therewith significant $\mathrm{ET}_{\mathrm{c}}$ and yield limitations. Diminishing available water resources would cause critical water shortage problems. Consequently, the studies for accurate estimations of water consumption to save water, gain importance (Oweis et al., 2000; Li et al., 2001; Fabeiro et al., 2001). However, more studies are still needed for deficit irrigation of vegetables (Chartzoulakis and Drosos, 1995; Mendezr, 1987, Mannini and Gallina, 1996).

On the other hand incorporation of saline water in irrigation leads to a decrease in transpiration (Dudley et al., 2008), which subsequently results in reduced $\mathrm{ET}_{\mathrm{c}}$. Linear decreases in $\mathrm{ET}_{\mathrm{c}}$ with different irrigation water salinity, have been observed for a number of crops including: corn, alfalfa date palm (Tripler et al., 2007), tomato (Ben-Gal et al., 2003; Shani et al., 2007), grapevine (Shani \& Ben-Gal, 2005; Shani et al., 2007), tall wheat grass (Skaggs et al., 2006), melon (Shani and Dudley, 2001; Skaggs et al., 2006), onion, bell pepper and sunflower (Shani et al., 2007; Ben-Gal et al., 2008). A good correlation was met between relative decrease in yield and relative decrease in evapotranspiration with the aforesaid crops under different levels of salinity. Blanco and Folegatti (2003) showed a 4.6\% decrease in ET per unit increase of water salinity for cucumber.

Despite the considerable research on predicting the effects of irrigation regimes or saline water on crop yield and $\mathrm{ET}_{\mathrm{c}}$ in outdoor cultivation (Doorenbos and Kassam, 1986; Ouda et al. 2006 and Katerji et al., 1998), only a few 
studies have spotted the combination of salinity and drought stresses especially in greenhouse cultivation.

Eggplant is an economically important vegetable crop, produced as 35.3 million tons from 1.9 million ha worldwide. $93 \%$ of the eggplant production takes place in Asia, while $7 \%$ is produced in Africa, Europe and America. Eggplant is ranked fourth within the greenhouse products, after tomato, pepper and cucumber (Boyaci, 2007). There has been conflicting results on eggplant tolerance to drought stress and soil salinity. For example, eggplant is classified as a moderately sensitive vegetable crop (Maas, 1984), whereas Bresler et al. (1982) classified it as salt sensitive.

This investigation aims to compare the impact of salinity and drought stresses, besides environmental parameters, on eggplant yield and evapotranspiration of eggplant in greenhouse and outdoor environments.

\section{Materials and Methods}

\subsection{Area Descriptions}

Experiments were carried out on eggplant (Solanum melongena L.) crops in an unheated plastic greenhouse (with dimensions: height $4.0 \mathrm{~m}$, length $12.0 \mathrm{~m}$, width $10 \mathrm{~m}$ and $120 \mathrm{~m}^{2}$ area) and the adjacent field with an area of $1500 \mathrm{~m}^{2}$ located in Badjgah $\left(29^{\circ} 36^{\prime} \mathrm{N}, 52^{\circ} 32^{\prime} \mathrm{E}\right)$, College of Agriculture, Shiraz University, Shiraz, Iran. An automatic weather station was installed in the central part of the greenhouse to measure net radiation $(\mathrm{Rn})$, air temperature (Ta) and relative humidity $(\mathrm{RH})$. The Same system was utilized in the nearby college weather station for monitoring the outdoor data.

Anamur RZ cultivar of eggplant, which is commonly grown in either fields or greenhouses, was utilized. Eggplant seeds were sown on March $18^{\text {th }}$ and April $9^{\text {th }}$ in the first and second year, respectively. On May $5^{\text {th }}, 2012$ and May $18^{\text {th }}, 2013$, uniform seedlings (about $15 \mathrm{~cm}$ in height with four leaves) were transplanted to both the field ground and plastic pots and were filled with the same ground soil from the same depth. Some physical and chemical soil features are presented in Table 1. According to the chemical properties of the soil, $1 \mathrm{~g}$ mono ammonium phosphate was implemented for each soil pot before transplanting, and $2 \mathrm{~g}$ potassium nitrate was applied to each pot as 50\%,25\% and $25 \%$ in three stages during growth period (i.e. transplant, beginning of the flowering and the start of harvest respectively).

After the establishment of plants (14 days after transplanting), drought and salinity treatments were initiated on May $19^{\text {th }}, 2012$ and June $1^{\text {st }}, 2013$.

Table 1. Some physical and chemical of the soil

\begin{tabular}{lllllllll}
\hline Soil & Field Capacity & Wilting Point & Bulk Density & $\mathrm{pH}$ & $\mathrm{ECe}$ & $\mathrm{N}_{\text {total }}$ & $\mathrm{K}$ & $\mathrm{P}$ \\
\hline Depth $(\mathrm{m})$ & (Mass Percent) & (Mass Percent) & $\left(\mathrm{gr} \mathrm{cm}^{-3}\right)$ & & $\left(\mathrm{ds} \mathrm{m}^{-1}\right)$ & $(\%)$ & $\left(\mathrm{mg} \mathrm{Kg}^{-1}{ }_{\text {soil }}\right)$ & $\left(\mathrm{mg} \mathrm{Kg}^{-1}\right.$ soil $)$ \\
$0-0.3$ & 30.5 & 11 & 1.03 & 7.72 & 0.55 & 0.2 & 600 & 12.5 \\
\hline
\end{tabular}

\subsection{Treatments}

The experiment was carried out according to a completely randomized design with three replicates per treatment. Irrigation frequency treatments consisted of: $\mathrm{I}_{1}$, daily irrigation; $\mathrm{I}_{2}$, irrigation at pot capacity level per every week interval; $I_{3}$, irrigation at pot capacity level per two weeks interval. Four saline irrigation waters with electrical conductivities of $\mathrm{J}_{1}, 0.8$ (tap water); $\mathrm{J}_{2}, 2.5 ; \mathrm{J}_{3}, 5.0$ and $\mathrm{J}_{4}, 7.0 \mathrm{dS} \mathrm{m}^{-1}$ were utilized as saline water treatments. The $\mathrm{I}_{1} \mathrm{~J}_{1}$ treatment (daily irrigation with tab water) was assigned as control treatment. Same 12 combinational drought/salinity treatments were utilized for greenhouse and outdoor experiments. In the greenhouse, plastic pots with $35 \mathrm{~cm}$ diameters and $60 \mathrm{~cm}$ heights were utilized for each treatment as microlysimeters. In outdoor cultivation a block was allocated to each treatment, in which 9 crops were grown. A similar pot, used as each treatment microlysimeter was installed on the ground in the center of each block.

\subsection{Irrigation}

Pots were irrigated up to field capacity throughout the experiment. The field capacity of each pot was determined at the beginning of the experiment by saturating pots with tap water. The water content of the covered pots after the drainage stopped was assumed to be field capacity $\left(W_{F C}\right)$. Before each irrigation event, pots were weighed and the weight of irrigation water amount $\left(W_{I}\right)$ was calculated as

$$
W_{I}=\frac{W_{F C}-W}{1-L F}
$$


In which, $W$ and $W_{F C}$ are the pot weight (g) just before irrigation and at field capacity respectively and $L F$ is leaching fraction, which was set to a target of 0.15 as suggested by Ayers and Westcot (1985) for efficient irrigation. Leachate was collected and measured after irrigation using empty pots placed underneath each pot.

\subsection{Evapotranspiration}

Since there was no capillary water entrance from the water table, runoff loss, and no precipitation during the experiment, the final equation obtained from water balance method (James, 1988) to measure daily evapotranspiration was:

$$
E T=\frac{\left[\frac{\left(W_{n}-W_{n+1}\right)+\left(W_{I}-W_{D p}\right)}{\rho_{w}}\right]}{A}
$$

Where, $E T$ is the daily evapotranspiration (cm), $W_{I}$ and $W_{D p}$ are the amounts of applied and drainage water $(\mathrm{g})$, $W_{n}$ and $W_{n+1}$ are pot weights in two consecutive days $(\mathrm{g}), r_{W}$ is water bulk density $\left(1 \mathrm{~g} \mathrm{~cm}^{-3}\right)$ and $A$ is the top area of the cylindrical pots $\left(\mathrm{cm}^{2}\right)$. As the weights of the pots were taken daily and weight loss from each day was calculated using their preceding weights only, possible error due to the plant weight increase was indeed very little and negligible.

\subsection{Harvest}

Fruits were hand-harvested occasionally in August and September. Number of fruits and fruit weight per plant and some quality characteristics of eggplants such as mean fruit weight, diameter and length were determined. The plants were cut at $1 \mathrm{~cm}$ above the soil surface, at the end of the experiment (on September $5^{\text {th }}, 2012$ and September $22^{\text {nd }}, 2013$ ), and the stem diameter and dry weight (oven-dried at $70^{\circ} \mathrm{C}$ to a constant weight) were obtained for each replication. The plant root lengths and dry weight from each pot were measured.

In the end, soil samples taken from each pot, were air dried and passed through a 2-mm screen. Saturated soil pastes were prepared, and saturation extracts were taken after $24 \mathrm{~h}$ and their electrical conductivities (ECe) were measured.

\subsection{Modeling Yield Response}

According to the theory of de Wit (1958) crop yield $(Y)$ is a linear function of its transpiration $(T)$. This theory was the basis for several models to predict yield from evapotranspiration (Rijtema and Endrodi, 1970; Hanks, 1974).

A simple, linear crop-water production function introduced in the FAO Irrigation and Drainage Paper No33 (Doorenbos, J. and Kassam, A. H., 1979) was evaluated to predict the reduction in crop yield when crop stress was caused by a shortage of soil water and salinity:

$$
\left(1-\frac{Y_{a}}{Y_{m}}\right)=K y\left(1-\frac{E T c}{E T c_{s t d}}\right)
$$

Where, $Y_{a}$ and $Y_{m}$ are the actual and maximum (for no stress conditions) crop yield respectively, $K y$ is the yield response factor, $E T_{c}$ is the actual crop evapotranspiration and $E T_{c s t d}$ is the crop evapotranspiration for standard conditions $\left(\mathrm{I}_{1} \mathrm{~J}_{1}\right.$ treatment).

The salt tolerance model suggested by Maas and Hoffman (1977) was evaluated by the computer program developed by van Genuchten (1983) for fruit yield and the threshold soil salinity value and slope value beyond the threshold value were calculated. The salt tolerance model suggested by Maas and Hoffman (1977) is:

$$
\frac{Y_{a}}{Y_{m}}=1-\left(E C e-E C e_{\text {threshold }}\right) \frac{b}{100}
$$

Where, $E C e_{\text {threshold }}$ is threshold soil salinity $\left(\mathrm{dSm}^{-1}\right)$ beyond which yield decreases, $E C e$ is either the soil salinity of the extract or ECe threshold, whichever is greater $\left(\mathrm{dSm}^{-1}\right)$ and $b$ is the slope value which is the percentage yield loss per unit increase in electrical conductivity of the saturated soil extract beyond the threshold value. 


\subsection{Statistical Analysis}

The experimental data were analyzed using the SAS statistical analysis software package. Simple analysis of variance was applied to determine the effects of different levels of watering and salinity on the studied parameters in each environment separately. A compound analysis of variance was also used to compare the effects of such factors in greenhouse with outdoor conditions. All statistical tests were performed at the 0.05 level of significance. Duncan's test was applied to determine the differences between the averages of the groups.

\section{Results}

\subsection{Climatic Data}

The meteorological data of the outdoor and greenhouse stations covering the experiment period from were analyzed for purposes of calculating evapotranspiration. Figure 1 shows daily temperature, relative humidity, daily pan evaporation and net radiation data for greenhouse and outdoor conditions respectively.

\subsection{Irrigation}

Irrigation was carried out in fixed intervals to provide field capacity moisture in the 0 to $30 \mathrm{~cm}$ soil depth of each pot. Total irrigation water amount and number of irrigations utilized in each treatment in outdoor and greenhouse cultivations, are indicated in Table 2 . The lowest and highest irrigation waters were applied to $I_{1} J_{1}$ and $I_{3} J_{4}$ in both outdoor and greenhouse treatments.

\subsection{Daily ETc}

Daily evapotranspiration measurements for outdoor and greenhouse conditions are shown in Figure 2, respectively. Each Figure contains the $\mathrm{ET}_{\mathrm{c}}$ variations during the growing season for daily (a), weekly (b) and two weeks (c) irrigation treatments during the first and second cultivation. Peak values of daily $\mathrm{ET}_{\mathrm{c}}$ measured in outdoor pots for $I_{1}$ treatments ranged from 14 to $7.4 \mathrm{~mm}$ for $\mathrm{I}_{1} \mathrm{~J}_{1}$ and $\mathrm{I}_{1} \mathrm{~J}_{4}$, respectively, while the highest daily $E_{c}$ values for $I_{2}$ changed from 12.2 to $5.8 \mathrm{~mm}$ for $\mathrm{I}_{2} \mathrm{~J}_{1}$ and $\mathrm{I}_{2} \mathrm{~J}_{4}$, respectively. Such values were 6.6 and $3 \mathrm{~mm}$ for $\mathrm{I}_{3} \mathrm{~J}_{1}$ and $\mathrm{I}_{3} \mathrm{~J}_{4}$ treatments, respectively. Daily $\mathrm{ET}_{\mathrm{c}}$ peak values measured in greenhouse pot changed from 10.2 to $5.9 \mathrm{~mm}$ in $\mathrm{I}_{1}$ treatments for $\mathrm{I}_{1} \mathrm{~J}_{1}$ and $\mathrm{I}_{1} \mathrm{~J}_{4}$, respectively. In $\mathrm{I}_{2}$ treatments such values were between 7.9 and $4.1 \mathrm{~mm}$ for $\mathrm{I}_{2} \mathrm{~J}_{1}$ and $\mathrm{I}_{2} \mathrm{~J}_{4}$, respectively, while in $\mathrm{I}_{3}$ treatment pot 5.0 and $2.6 \mathrm{~mm}$ were met for extreme daily $\mathrm{ET}_{\mathrm{c}}$ values for $\mathrm{I}_{3} \mathrm{~J}_{1}$ and $\mathrm{I}_{3} \mathrm{~J}_{4}$, respectively.
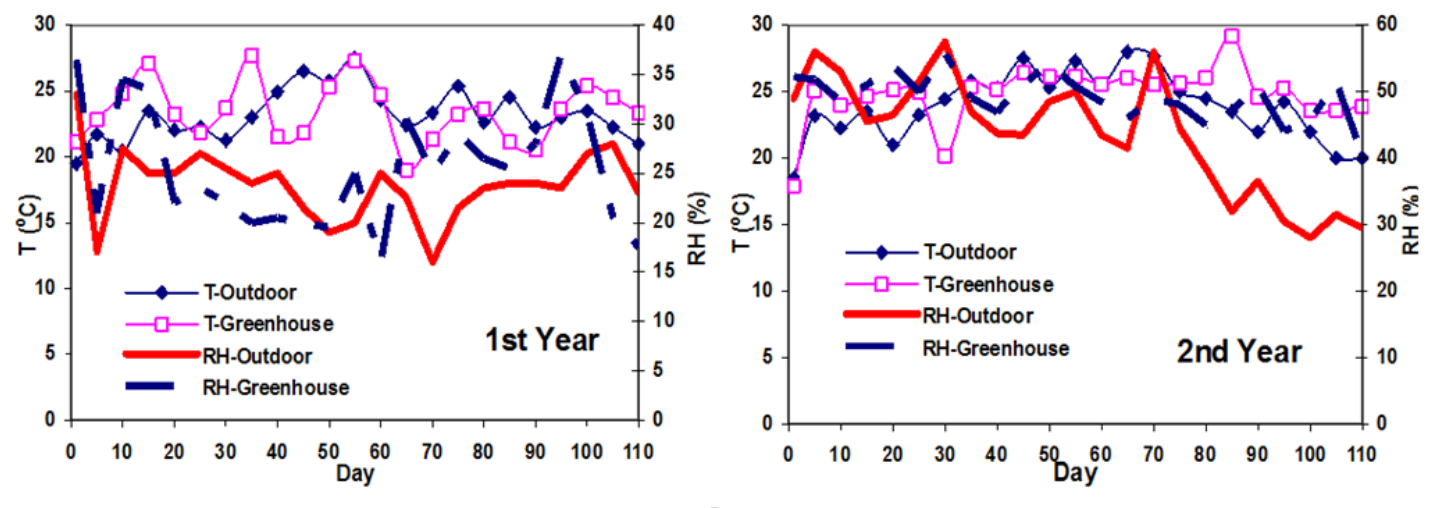

a
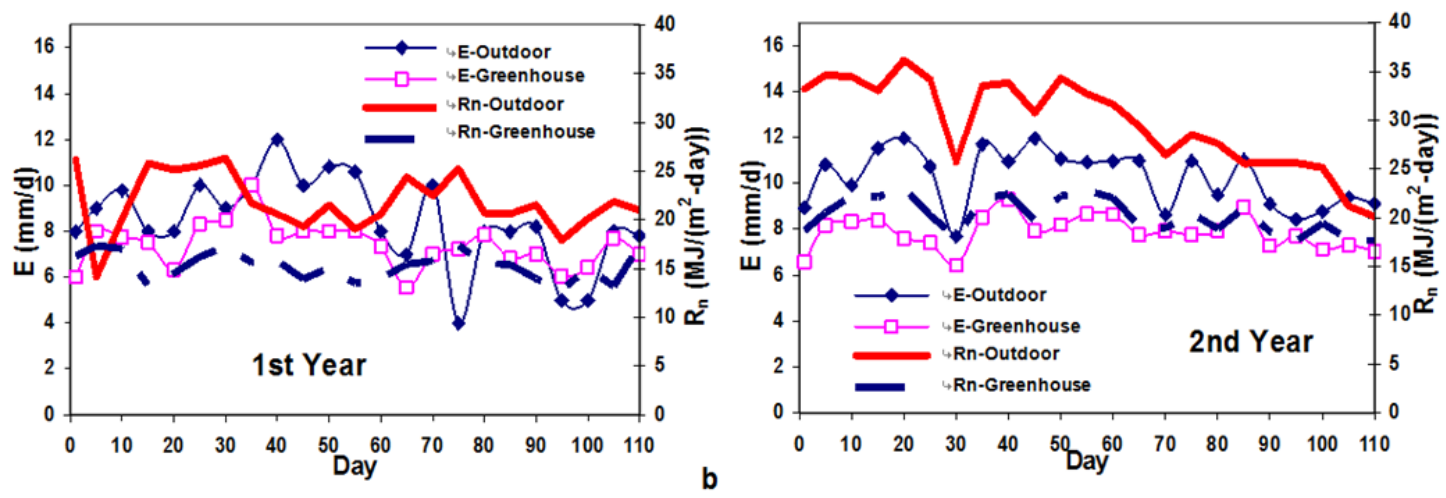

Figure 1. Daily variations of a) temperature $(T)$ and relative humidity $(R H)$ and $b)$ net radiation $\left(R_{n}\right)$ and pan evaporation $(\mathrm{E})$ 
Table 2. Number of irrigation and total amounts of irrigation water applied (mm) in outdoor and greenhouse treatments

\begin{tabular}{cccccccccccccc}
\hline Treatment & $\mathrm{I}_{1} \mathrm{~J}_{1}$ & $\mathrm{I}_{1} \mathrm{~J}_{2}$ & $\mathrm{I}_{1} \mathrm{~J}_{3}$ & $\mathrm{I}_{1} \mathrm{~J}_{4}$ & $\mathrm{I}_{2} \mathrm{~J}_{1}$ & $\mathrm{I}_{2} \mathrm{~J}_{2}$ & $\mathrm{I}_{2} \mathrm{~J}_{3}$ & $\mathrm{I}_{2} \mathrm{~J}_{4}$ & $\mathrm{I}_{3} \mathrm{~J}_{1}$ & $\mathrm{I}_{3} \mathrm{~J}_{2}$ & $\mathrm{I}_{3} \mathrm{~J}_{3}$ & $\mathrm{I}_{3} \mathrm{~J}_{4}$ \\
\hline Number of Irrigation & 110 & 110 & 110 & 110 & 16 & 16 & 16 & 16 & 8 & 8 & 8 & 8 \\
$\begin{array}{c}\text { Outdoor Irrigation } \\
\text { Water Applied }\end{array}$ & 1st Year & 924.3 & 758.6 & 682.1 & 610.4 & 662.8 & 539.1 & 482.5 & 447.1 & 481.5 & 356.6 & 308.8 & 277.6 \\
& 2nd Year & 1036.3 & 870.8 & 756.9 & 634.5 & 769.3 & 630.0 & 548.0 & 471.0 & 531.2 & 401.3 & 323.2 & 271.8 \\
$\begin{array}{c}\text { Greenhouse Irrigation } \\
\text { Water Applied }\end{array}$ & 1st Year & 676.2 & 573.7 & 521.0 & 463.5 & 460.8 & 363.7 & 345.7 & 313.1 & 293.1 & 236.2 & 235.4 & 213.8 \\
\hline
\end{tabular}

\subsection{ECe Values}

The changes of measured soil extract salinity, with different watering frequencies and levels of water salinity for outdoor and greenhouse treatments are given in Table 3. In outdoor conditions, the maximum ECe value measured in $\mathrm{I}_{1}$ treatments were $11.4 \mathrm{ds} / \mathrm{m}$ (in the first year) while such value reached $18.8 \mathrm{ds} / \mathrm{m} \mathrm{in}_{3}$ treatments (in the second year). A similar trend was met in ECe variations in greenhouse for both years, however the effect of irrigation water salinity was more evident in each treatment, while the intensity of water deficit was less effective in the ECe values. The ECe values ranged from $1.6\left(\mathrm{I}_{1} \mathrm{~J}_{1}\right)$ to $13.9\left(\mathrm{I}_{1} \mathrm{~J}_{4}\right) \mathrm{ds} / \mathrm{m}$ in $\mathrm{I}_{1}$ treatments, while in $\mathrm{I}_{3}$ an increase from 2.7 to $16.4 \mathrm{ds} / \mathrm{m}$ was observed.
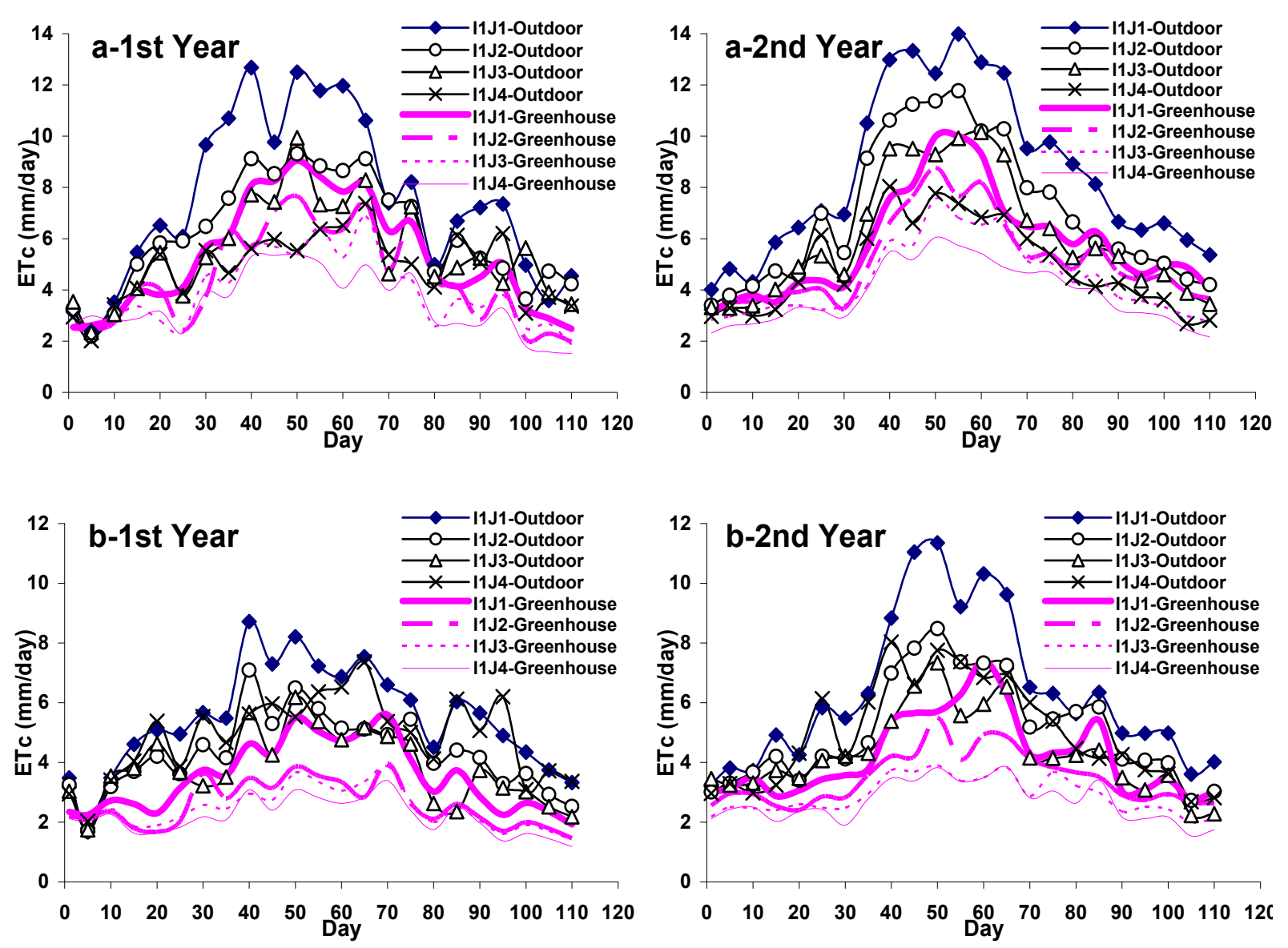

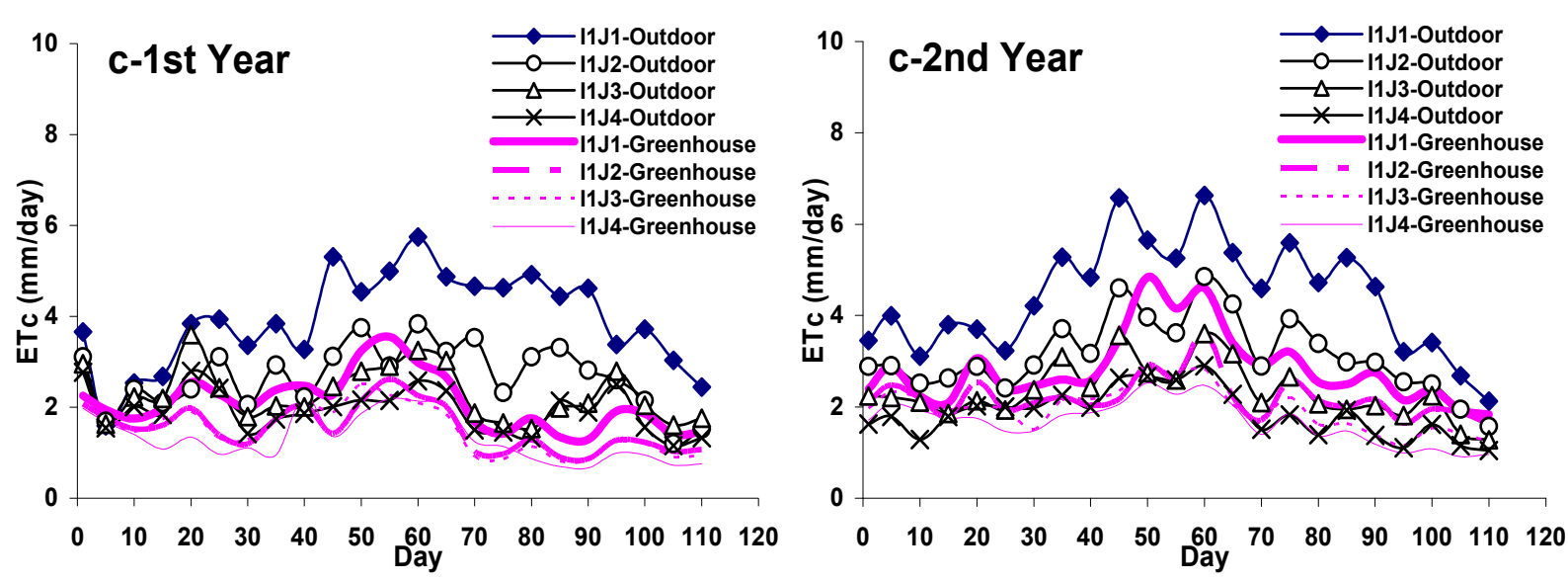

Figure 2. Daily $E T_{c}$ variations for a) $\left.I_{1}, b\right) I_{2}$ and c) $I_{3}$ irrigation treatments applying water with different salinity in outdoor and greenhouse eggplants

Table 3. Effect of different levels of water deficit and salinity on the experimental soil and plant properties in outdoor and greenhouse conditions*

\begin{tabular}{|c|c|c|c|c|c|c|c|c|c|c|}
\hline \multirow{2}{*}{ Treatment } & \multicolumn{2}{|c|}{ ETc (mm) } & \multicolumn{2}{|c|}{ Ece (ds/m) } & \multicolumn{2}{|c|}{$\mathrm{Y}$ (gr/plant) } & \multicolumn{2}{|c|}{ Fruit Diameter $(\mathbf{c m})$} & \multicolumn{2}{|c|}{ Shoot DW (g/plant) } \\
\hline & 1st Year & 2nd Year & 1st Year & 2nd Year & 1st Year & 2nd Year & 1st Year & 2nd Year & 1st Year & 2nd Year \\
\hline \multicolumn{11}{|l|}{ Outdoor } \\
\hline $\mathrm{I}_{1} \mathrm{~J}_{1}$ & 846.6 a & 954.6 a & $2.7 \mathrm{e}$ & $3.1 \mathrm{~g}$ & $2490.1 \mathrm{ab}$ & 2587.4 a & $6.5 \mathrm{a}$ & $7.1 \mathrm{a}$ & 38.7 a & $43.5 \mathrm{a}$ \\
\hline $\mathrm{I}_{1} \mathrm{~J}_{2}$ & $680.9 \mathrm{~b}$ & $789.0 \mathrm{~b}$ & $8.5 \mathrm{~d}$ & 7.2 ef & $1713.2 \mathrm{~cd}$ & 1748.2 bc & $5.9 a b$ & $6.0 \mathrm{abc}$ & $34.1 \mathrm{ab}$ & 36.6 a \\
\hline $\mathrm{I}_{1} \mathrm{~J}_{3}$ & 604.4 bc & $675.1 \mathrm{c}$ & $10.6 \mathrm{~cd}$ & $9.3 \mathrm{~d}$ & $1690.8 \mathrm{~cd}$ & $1714.1 \mathrm{bc}$ & $5.2 \mathrm{abc}$ & $5.2 \mathrm{abcd}$ & 29.4 bc & 27.7 bc \\
\hline $\mathrm{I}_{1} \mathrm{~J}_{4}$ & $532.7 \mathrm{~cd}$ & $552.8 \mathrm{~d}$ & $11.4 \mathrm{~cd}$ & $9.5 \mathrm{~d}$ & $1536.4 \mathrm{cde}$ & $1429.7 \mathrm{~cd}$ & $3.8 \mathrm{cde}$ & 4.9 bcd & $26.0 \mathrm{bc}$ & $28.0 \mathrm{~b}$ \\
\hline $\mathrm{I}_{2} \mathrm{~J}_{1}$ & $604.7 \mathrm{bc}$ & 707.5 c & $3.2 \mathrm{e}$ & $6.7 \mathrm{f}$ & $2720.3 \mathrm{a}$ & 2019.3 b & $6.1 \mathrm{a}$ & $6.5 \mathrm{ab}$ & $41.0 \mathrm{a}$ & $41.7 \mathrm{a}$ \\
\hline $\mathrm{I}_{2} \mathrm{~J}_{2}$ & 476.6 cde & $564.2 \mathrm{~d}$ & $9.8 \mathrm{~d}$ & $9.9 \mathrm{~d}$ & $1723.2 \mathrm{~cd}$ & 1658.4 bc & $5.5 a b$ & $6.1 \mathrm{abc}$ & 38.4 a & 39.2 a \\
\hline $\mathrm{I}_{2} \mathrm{~J}_{3}$ & 417.9 def & $478.5 \mathrm{e}$ & $12.8 \mathrm{bc}$ & $13.2 \mathrm{c}$ & 1282.4 cdef & $1351.6 \mathrm{~cd}$ & $5.0 \mathrm{abcd}$ & $6.0 \mathrm{abc}$ & $28.0 \mathrm{bc}$ & 26.5 bc \\
\hline $\mathrm{I}_{2} \mathrm{~J}_{4}$ & $380.3 \mathrm{efg}$ & $400.1 \mathrm{f}$ & $15.2 \mathrm{ab}$ & $15.7 \mathrm{~b}$ & 806.8 def & 993.4 de & 3.5 de & $4.2 \mathrm{~cd}$ & $25.0 \mathrm{bcd}$ & $24.4 \mathrm{bc}$ \\
\hline $\mathrm{I}_{3} \mathrm{~J}_{1}$ & 439.2 de & $482.6 \mathrm{e}$ & $4.3 \mathrm{e}$ & 7.9 e & 1909.9 bc & 1878.2 bc & $4.4 \mathrm{bcd}$ & $5.1 \mathrm{abcd}$ & $27.9 \mathrm{bc}$ & 25.5 bc \\
\hline $\mathrm{I}_{3} \mathrm{~J}_{2}$ & $299.6 \mathrm{fgh}$ & $344.7 \mathrm{f}$ & $14.4 \mathrm{~b}$ & 14.7 b & 1165.4 cdef & $1376.7 \mathrm{~cd}$ & 3.8 cde & $3.8 \mathrm{~d}$ & $20.6 \mathrm{~cd}$ & $22.0 \mathrm{bc}$ \\
\hline $\mathrm{I}_{3} \mathrm{~J}_{3}$ & $251.4 \mathrm{gh}$ & $261.0 \mathrm{~g}$ & $14.4 \mathrm{~b}$ & 15.2 b & 956.2 def & 963.7 de & $3.3 \mathrm{de}$ & $4.2 \mathrm{~cd}$ & $22.3 \mathrm{~cd}$ & 23.4 bc \\
\hline $\mathrm{I}_{3} \mathrm{~J}_{4}$ & $215.7 \mathrm{~h}$ & $205.0 \mathrm{~g}$ & 17.4 a & $18.8 \mathrm{a}$ & $527.9 \mathrm{f}$ & 598.9 e & $2.7 \mathrm{e}$ & $3.5 \mathrm{~d}$ & $16.6 \mathrm{~d}$ & 19.7 c \\
\hline \multicolumn{11}{|l|}{ Greenhouse } \\
\hline $\mathrm{I}_{1} \mathrm{~J}_{1}$ & 598.5 a & 657.2 a & $1.6 \mathrm{~d}$ & $2.0 \mathrm{~h}$ & $2405.3 \mathrm{ab}$ & 2510.0 a & $6.0 \mathrm{a}$ & $6.6 \mathrm{a}$ & 36.7 a & 40.8 a \\
\hline$I_{1} J_{2}$ & $495.9 \mathrm{~b}$ & 588.6 b & $9.9 \mathrm{c}$ & $6.8 \mathrm{f}$ & 1849.7 c & 1869.1 b & $5.2 a b$ & $5.6 \mathrm{abc}$ & $31.2 \mathrm{ab}$ & $32.0 \mathrm{bc}$ \\
\hline $\mathrm{I}_{1} \mathrm{~J}_{3}$ & 443.3 bc & $493.8 \mathrm{c}$ & 11.6 bc & $10.6 \mathrm{c}$ & $1141.5 \mathrm{de}$ & $1424.5 \mathrm{~d}$ & $4.5 \mathrm{bc}$ & $5.0 \mathrm{bcd}$ & $28.1 \mathrm{bc}$ & $28.5 \mathrm{bcd}$ \\
\hline $\mathrm{I}_{1} \mathrm{~J}_{4}$ & $385.8 \mathrm{~cd}$ & 431.4 de & 13.9 ab & $11.0 \mathrm{c}$ & 1006.4 def & 1210.2 de & $4.2 \mathrm{bc}$ & $4.5 \mathrm{cde}$ & $25.7 \mathrm{bcd}$ & 31.3 bc \\
\hline $\mathrm{I}_{2} \mathrm{~J}_{1}$ & $394.2 \mathrm{~cd}$ & $475.0 \mathrm{~cd}$ & $2.1 \mathrm{~d}$ & $3.3 \mathrm{~g}$ & $2679.0 \mathrm{a}$ & 2290.3 a & $6.0 \mathrm{a}$ & $6.4 \mathrm{a}$ & $37.2 \mathrm{a}$ & 39.3 a \\
\hline $\mathrm{I}_{2} \mathrm{~J}_{2}$ & $294.3 \mathrm{de}$ & 379.7 e & 11.7 bc & 8.4 e & $1590.0 \mathrm{~cd}$ & $1516.7 \mathrm{~cd}$ & $5.5 a b$ & $6.2 \mathrm{ab}$ & $32.1 \mathrm{ab}$ & 34.8 ab \\
\hline $\mathrm{I}_{2} \mathrm{~J}_{3}$ & 275.9 e & $323.0 \mathrm{f}$ & 11.6 bc & $10.3 \mathrm{~cd}$ & 962.1 ef & $1411.1 \mathrm{~d}$ & $5.2 \mathrm{ab}$ & $5.5 \mathrm{abc}$ & $29.3 \mathrm{ab}$ & $27.4 \mathrm{bcd}$ \\
\hline $\mathrm{I}_{2} \mathrm{~J}_{4}$ & 242.2 ef & $301.2 \mathrm{fg}$ & $14.0 \mathrm{ab}$ & $12.6 \mathrm{~b}$ & 779.3 ef & $1184.7 \mathrm{de}$ & $3.0 \mathrm{~cd}$ & $3.6 \mathrm{de}$ & $26.8 \mathrm{bcd}$ & $28.2 \mathrm{bcd}$ \\
\hline $\mathrm{I}_{3} \mathrm{~J}_{1}$ & 233.4 ef & $318.0 \mathrm{f}$ & $2.7 \mathrm{~d}$ & $5.5 \mathrm{f}$ & 2080.6 bc & 1781.6 bc & $4.3 \mathrm{bc}$ & $4.8 \mathrm{bcde}$ & $31.1 \mathrm{ab}$ & $21.4 \mathrm{~d}$ \\
\hline $\mathrm{I}_{3} \mathrm{~J}_{2}$ & $171.4 \mathrm{f}$ & $249.1 \mathrm{gh}$ & 11.9 bc & $9.0 \mathrm{de}$ & 914.0 ef & $1212.0 \mathrm{~d}$ & $3.2 \mathrm{~cd}$ & $3.4 \mathrm{e}$ & $23.9 \mathrm{bcd}$ & $24.5 \mathrm{~cd}$ \\
\hline $\mathrm{I}_{3} \mathrm{~J}_{3}$ & $169.3 \mathrm{f}$ & $217.4 \mathrm{hi}$ & $12.5 \mathrm{bc}$ & $12.7 \mathrm{~b}$ & 779.3 ef & 893.0 ef & $3.6 \mathrm{~cd}$ & 3.9 de & 20.9 bcd & $25.6 \mathrm{~cd}$ \\
\hline $\mathrm{I}_{3} \mathrm{~J}_{4}$ & $145.3 \mathrm{f}$ & $187.3 \mathrm{i}$ & $16.4 \mathrm{a}$ & 16.3 a & $497.9 \mathrm{f}$ & $789.0 \mathrm{f}$ & $2.7 \mathrm{~d}$ & $3.3 \mathrm{e}$ & $19.1 \mathrm{~d}$ & $22.0 \mathrm{~d}$ \\
\hline
\end{tabular}

NS: non-significant

*values followed by the same letter are not significantly different according to Duncan's multiple range test at 0.05 significance level

\subsection{Yield and Vegetative Growth}

Values regarding eggplant total evapotranspiratoin and mean yield parameters in outdoor and greenhouse conditions are presented in Table 3. It is mentionable that some vegetative growth parameters such as number of fruits, fruit height, plant height, root length and stem diameter were not significantly affected by the treatments applied and therefore not indicated in the Table. The average values obtained for these parameters were 10, 20 
$\mathrm{cm}, 11 \mathrm{gr} /$ plant, $61 \mathrm{~cm}, 31 \mathrm{~cm}$ and $11 \mathrm{~mm}$, respectively. These parameters were not significantly different, neither in outdoor and greenhouse conditions nor in the first and second cultivation. The differences of the treatments were indicated with the Latin letters in the Duncan's test result. During the two year experiments, the highest yield was obtained from $\mathrm{J}_{1}$ while the lowest yields were observed in $\mathrm{J}_{4}$ treatments, in outdoor eggplants. Similarly, $\mathrm{J}_{1}$ treatments obtained the highest yield in greenhouse eggplants, while the lowest yields belonged to $\mathrm{I}_{3} \mathrm{~J}_{3}$ and $\mathrm{I}_{3} \mathrm{~J}_{4}$.

The relationships between relative decrease in yield (1- Y/Ym) and relative decrease in evapotranspiration (1$\mathrm{ET}_{\mathrm{c}} / \mathrm{ET}_{\mathrm{m}}$ ) in outdoor and greenhouse conditions are shown in Figure 3. The $\mathrm{K}_{\mathrm{y}}$ coefficient obtained for irrigation and water salinity treatments in the first year were 0.97 and 1.03 for outdoor and greenhouse eggplants, respectively. Such values were 0.91 and 0.92 in the second year of experiment. The $\mathrm{K}_{\mathrm{y}}$ values obtained for both years indicate that eggplant is moderately sensitive to water deficit and salinity stresses interaction.

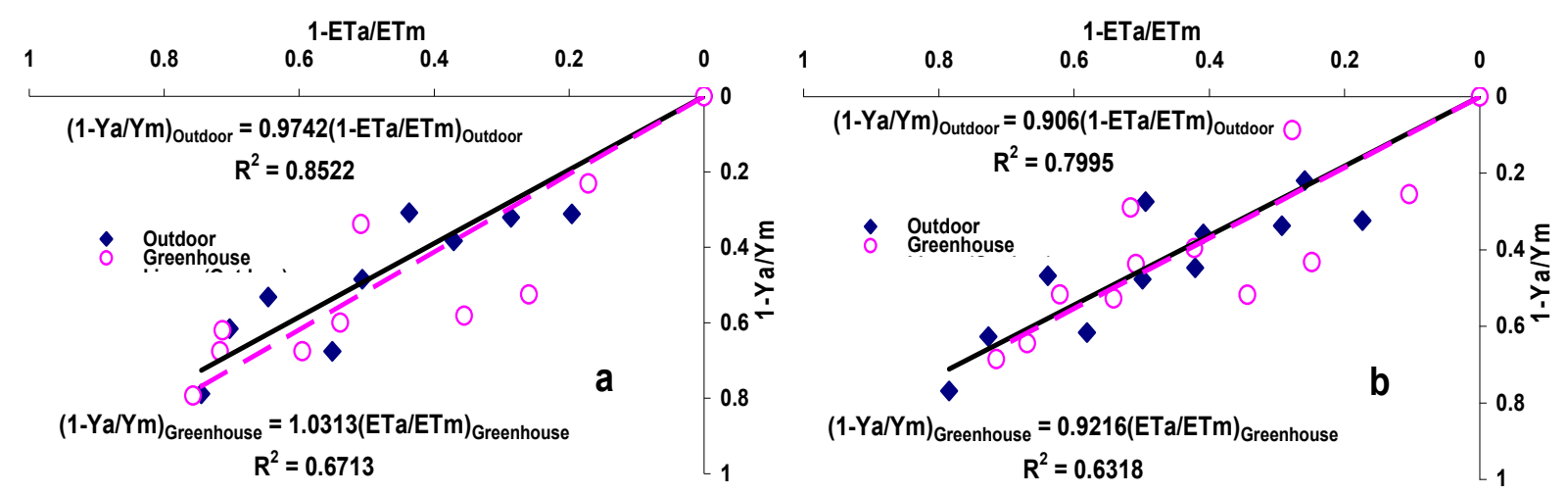

Figure 3. Relationships between relative yield decrease and relative evapotranspiration deficit for eggplant in outdoor and greenhouse conditions for the $1^{\text {st }}$ (a) and $2^{\text {nd }}$ (b) year of the experiment

The salt tolerance model suggested by Maas and Hoffman (1977) was also applied to study salinity effects on yield in each environment. The results for both years of the experiment are shown in Figure 4. The $\mathrm{ECe}_{\text {threshold }}$ and $b$ values obtained in outdoor and greenhouse conditions were $1.98 \mathrm{ds} / \mathrm{m}$ and $4.6 \%$ and $1.08 \mathrm{ds} / \mathrm{m}$ and $4.95 \%$

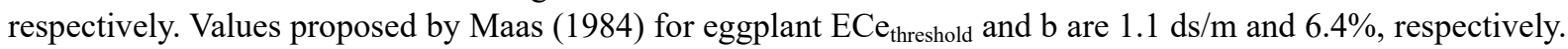
However, as expressed by Maas (1984), such values are considered as initial leading ones and absolute values of these parameters vary with different weather, soil and farming conditions. For example Unlukara et al (2010) obtained $1.5 \mathrm{ds} / \mathrm{m}$ and $4.4 \%$ for eggplant $\mathrm{ECe}_{\text {threshold }}$ and $\mathrm{b}$, respectively; which are partly close to those obtained in this study. For both years of experiment, outdoor b values were smaller than those of greenhouse and larger $\mathrm{ECe}_{\text {threshold }}$ values were obtained in outdoor conditions; which show the greenhouse eggplants being more sensitive to salinity in compare with the outdoor conditions.

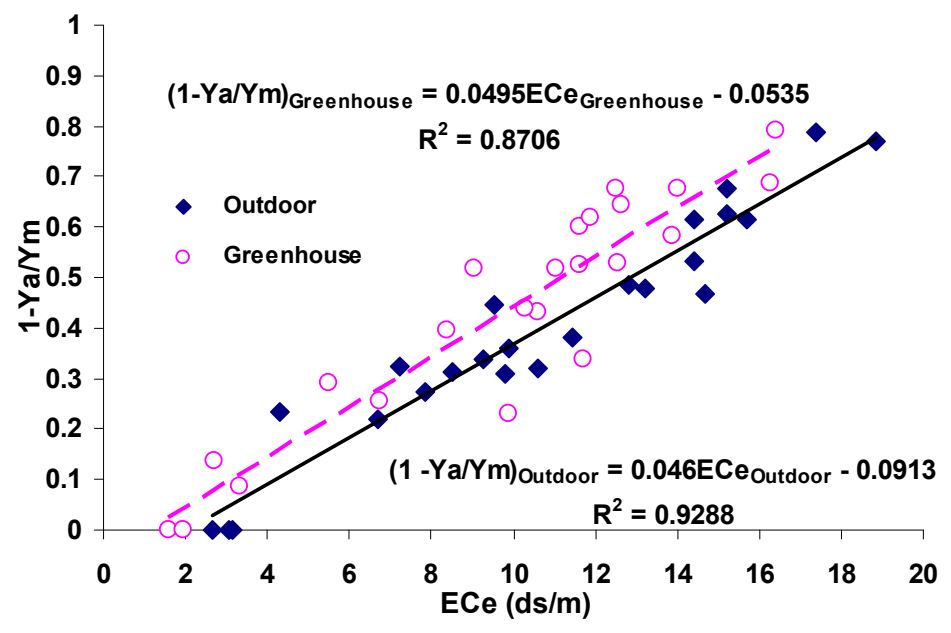

Figure. 4. Salt tolerance model for outdoor and greenhouse treatment 


\section{Discussion}

In both environments, the relative water loss was nearly similar during the early growth stages, in all treatments. In both years of experiment, almost three weeks after the initial treatment, variations in measured daily ETc, gradually became observable due to dissimilar irrigation frequency and water salinity.

Both in greenhouse and outdoor pots, $\mathrm{I}_{2}$ treatments showed an abrupt rise in daily $\mathrm{ET}_{\mathrm{c}}$ values one or two days after irrigation (Figure 2-b). The rate of such sudden increase was almost the same in both environments (max. 1.7 and $1.8 \mathrm{~mm}$ in 2 days in greenhouse and outdoor plants respectively) during both years. In $\mathrm{I}_{3}$ treatments, irrigation events brought about a milder increase in daily $\mathrm{ET}_{\mathrm{c}}$, relative to those of $\mathrm{I}_{2}$. As shown in Figure 2-b, daily $\mathrm{ET}_{\mathrm{c}}$ variation curves were smoother with smaller fluctuations. Such trend in daily $\mathrm{ET}_{\mathrm{c}}$ variations can also be met in $\mathrm{I}_{2}$ and $\mathrm{I}_{3}$ treatments with increase of salinity, just as shown in Figures 2-a and 2-b in which the increase of irrigation water EC has led to a decrease in the amplitude of the $\mathrm{ET}_{\mathrm{c}}$ fluctuations in daily $\mathrm{ET}_{\mathrm{c}}$ curves. Such smoothing in the trend of daily $\mathrm{ET}_{\mathrm{c}}$ variations toward watering frequency can be interpreted as the abatement of eggplant stomatal respond to irrigation as a result of salinity and drought stresses.

The results indicate that reductions in daily $\mathrm{ET}_{\mathrm{c}}$ values due to salinity were more significant in outdoor conditions than greenhouse ones during both years of experiment. The outdoor daily $\mathrm{ET}_{\mathrm{c}}$ of the $\mathrm{J}_{4}(\mathrm{EC}=0.8 \mathrm{ds} / \mathrm{m})$ treatments were shown to be 0.5 to 0.55 that of the $\mathrm{J}_{1}(\mathrm{EC}=7 \mathrm{ds} / \mathrm{m})$ treatments, while the ratio of the daily $\mathrm{ET}_{\mathrm{c}}$ of the $\mathrm{J}_{4}$ to $\mathrm{J}_{1}$ treatments were 0.62 to 0.67 in the greenhouse eggplants.

The difference between $\mathrm{I}_{1} \mathrm{~J}_{1}$ and other treatments were greater in outdoor condition than in the greenhouse. This indicates that outdoor eggplants' evapotranspiration are more sensitive to water deficiency. However, in both environments, the potential evaporative demand of eggplants decreased with lower water availability and quality. During soil moisture deficiency situations, water supply capability of the dried soil would become inadequate to meet the plant $\mathrm{ET}_{\mathrm{c}}$, mainly during its peak period of water use; which results in stomatal closure and total $\mathrm{ET}_{\mathrm{c}}$ reduction from 846.6 to $377.7 \mathrm{~mm}$ in outdoor $\mathrm{I}_{1} \mathrm{~J}_{1}$ to $\mathrm{I}_{3} \mathrm{~J}_{1}$ treatments and from 598.5 to $233.4 \mathrm{~mm}$ in greenhouse $I_{1} J_{1}$ to $I_{3} J_{1}$ treatments, respectively. During both years of experiment, a distinct decline in total $E T_{c}$ is observed versus water salinity increase. The total $\mathrm{ET}_{\mathrm{c}}$ under the greenhouse fresh water-irrigation conditions $\left(\mathrm{J}_{1}\right)$ is around 1.5 to 1.6 times higher than those in $\mathrm{J}_{4}$ treatments; while such ratio was between 1.6 and 1.8 in greenhouse treatments.

As indicated in the table 3, the ECe values escalated with increasing salinity levels, meanwhile, water deficit intensified soil extract salinity from $I_{1}$ to $I_{3}$ treatments in both outdoor and greenhouse environments. Results of an ANOVA analysis showed significant effects of water deficit and salinity factors on ECe values in both environments, for both years. However, the interaction of these factors revealed no significant difference in ECe values.

According to the Table 3, different watering regimes and salinity levels showed significant effects on $\mathrm{ET}_{\mathrm{c}}$ values in both environments $(p<0.05)$, however, no significant difference was observed between $\mathrm{J}_{3}$ and $\mathrm{J}_{4}$ treatments, in both years. Similarly, the interactive effects between irrigation and salinity treatments were not significant in both environments.

It was shown that irrigation and salinity treatments had significant effects on eggplant yield (Y). However, no significant difference was met between $\mathrm{I}_{1}$ and $\mathrm{I}_{2}$ treatments neither in outdoor nor in greenhouse conditions, in both years $(\mathrm{p}<0.05)$.

In both environments, despite the higher values of $\mathrm{ET}_{\mathrm{c}}$ during the growing season, eggplants' yield in $\mathrm{I}_{1} \mathrm{~J}_{1}$ treatments were lower than those in $\mathrm{I}_{2} \mathrm{~J}_{1}$; however, the differences were not significant. This can be related to the excess water, applied daily in $I_{1}$ treatments especially to obtain the leaching requirements, which led to more vegetative growth of plants and negatively affected fruit yield in $\mathrm{I}_{1}$ treatments.

The descending trend of ETc and $Y$ with the $I_{1}$ and $J_{1}$ treatments, were not the same in the greenhouse and outdoor eggplants. The ratio of the greenhouse to outdoor ETc values ranged from 0.53 to 0.73 , while the ratio of the greenhouse to outdoor $Y$ was between 0.65 and 1.1, in different treatments.

As shown in Figure 4 a very high relation $\left(\mathrm{R}^{2}=0.93\right)$ was observed between ECe as well as a relative decrease in yield of outdoor treatments. In the greenhouse treatments, however, salinity showed a less positive-effect $\left(\mathrm{R}^{2}=0.87\right)$ on yield decrease.

\subsection{Compound Analysis of Variance}

A compound analysis of variance was applied for a statistical comparison of I and $\mathrm{J}$ effects in greenhouse with outdoor conditions. In this analysis the environment was also considered as a source of variation. The results are 
presented in Table 4 for three major parameters $\left(\mathrm{ET}_{\mathrm{c}}\right.$, ECe and Y). Environment, I and J showed a significant effect on $\mathrm{ET}_{\mathrm{c}}$ at $5 \%$, while their interactional effects were not significant. The effect of environment on $\mathrm{Y}$ and ECe was not significant, nor its interactional effects with I and J. No significant difference was met between the results of first and second years of experiment according a compound analysis of variance applied between the two years data.

Table 4. Source of variation, related F-ratios and pr-values calculated from compound ANOVA from SAS software for the ETc, Y and ECe

\begin{tabular}{|c|c|c|c|c|c|c|c|c|c|c|c|c|c|}
\hline \multirow{3}{*}{ Source } & \multirow{3}{*}{ DF } & \multicolumn{6}{|c|}{ 1st Year } & \multicolumn{6}{|c|}{ 2nd Year } \\
\hline & & \multicolumn{2}{|c|}{ ETc } & \multicolumn{2}{|c|}{$\mathrm{Y}$} & \multicolumn{2}{|c|}{ Ece } & \multicolumn{2}{|c|}{ ETc } & \multicolumn{2}{|c|}{$\bar{Y}$} & \multicolumn{2}{|c|}{ Ece } \\
\hline & & $\bar{F}$ & Pr>F & $\mathbf{F}$ & Pr>F & $\bar{F}$ & Pr>F & $\bar{F}$ & Pr>F & $\mathbf{F}$ & Pr>F & $\mathbf{F}$ & $\mathrm{Pr}>\mathrm{F}$ \\
\hline Environment & 1 & 181.52 & $</ 0001^{*}$ & 6.04 & 0.0177 & 1.82 & 0.1837 & 330.18 & $</ 0001^{*}$ & 0.11 & 0.744 & 2.12 & 0.1521 \\
\hline I & 2 & 268.66 & $</ 0001^{*}$ & 36.17 & $</ 0001^{*}$ & 34.22 & $</ 0001^{*}$ & 638.06 & $</ 0001^{*}$ & 39.54 & $</ 0001^{*}$ & 30.13 & $</ 0001^{*}$ \\
\hline Environmentx| & 2 & 2.62 & 0.0835 & 0.77 & 0.47 & 7 & 0.0022 & 18.92 & $</ 0001^{*}$ & 1.14 & 0.3281 & 9 & 0.0017 \\
\hline$J$ & 3 & 54.83 & $</ 0001^{*}$ & 112.87 & $</ 0001^{*}$ & 310.06 & $</ 0001^{*}$ & 175.65 & $</ 0001^{*}$ & 72.37 & $</ 0001^{*}$ & 299.01 & $</ 0001^{*}$ \\
\hline $\mid x J$ & 6 & 1.39 & 0.2388 & 2.46 & 0.0372 & 1.79 & 0.1209 & 3.26 & 0.009 & 0.35 & 0.9087 & 3.22 & 0.09743 \\
\hline Environment $\times \mathrm{J}$ & 3 & 3.93 & 0.0138 & 1.57 & 0.2083 & 1.43 & 0.246 & 15.12 & $</ 0001$ & 0.41 & 0.7458 & 2.07 & 0.177 \\
\hline Environment $x \mid \times J$ & 6 & 0.14 & 0.991 & 1.01 & 0.429 & 1.65 & 0.1548 & 0.24 & 0.9621 & 0.92 & 0.4917 & 1.99 & 0.1128 \\
\hline
\end{tabular}

* Values are significant at $5 \%$

\section{Conclusions}

The relationship between irrigation regimes and water salinity with eggplant evapotranspiration, yield and some plant parameters were investigated in a plastic greenhouse and in outdoor conditions, during two 110 days experiment conducted in two successive years. Daily $\mathrm{ET}_{\mathrm{c}}$ measurements showed apparent variations between different irrigation regimes $\times$ water salinity treatments, during the early growing season. The reductions in daily $\mathrm{ET}_{\mathrm{c}}$ values due to salinity were more noticeable in outdoor conditions than in greenhouse ones. Higher sensitivity of outdoor eggplants to salinity was later demonstrated, obtaining higher values of $b$ and lower values of $E C e_{\text {threshold }}$ in the outdoor eggplants. In both environments, the cumulative $E_{\mathrm{c}}$ values decreased with decreasing water availability and quality. However, the differences between total $\mathrm{ET}_{\mathrm{c}}$ values were more obvious in the outdoor treatments than the greenhouse ones.

Both water deficit and salinity factors had significant effects on ECe values in both environments. Nonetheless, no significant difference was met between the treatments for irrigation regimes $\times$ water salinity interaction. Same results were obtained for total $\mathrm{ET}_{\mathrm{c}}, \mathrm{Y}$, fruit diameter and shoot dry weight.

The $\mathrm{K}_{\mathrm{y}}$ coefficient obtained for irrigation and water salinity treatments indicate that eggplant is moderately sensitive to water deficit and salinity stresses.

\section{References}

Allen, R. G., Pereira, L. S., Dirk, R., \& Smith, M. (1998). Crop evapotranspiration guidelines for computing crop water requirements, FAO, Rome, Italy.

Ayers, R. S., \& Westcot, D. W. (1985). Water quality for agriculture. FAO Irrigation and Drainage, 29, Rev. 1, Rome.

Ben-Gal, A., Ityel, E., Dudley, L., Cohen, S., Yermiyahu, U., Presnov, E., Zigmond, L., \& Shani, U. (2008). Effect of irrigation water salinity on transpiration and on leaching requirements: a case study for bell peppers. Agricultural Water Management. 95, 587-597. http://dx.doi.org/10.1016/j.agwat.2007.12.008

Ben-Gal, A., Karlberg, L., Janson, P. K., \& Shani, U. (2003). Temporal robustness of linear relationships between production and transpiration. Plant Soil, 251, 211-218. http://dx.doi.org/10.1023/A:1023004024653

Boyaci, H. F. (2007). Resistance resources and its inheritance against to fusarium wilt in eggplants, Cukurova University, Ph D Thesis, Natural and Applied Sciences. 108 p.

Bresler, E., McNeal, B. L., \& Carter, D. L. (1982). Saline and Sodic Soils. Springer-Verlag: Berlin. http://dx.doi.org/10.1007/978-3-642-68324-4

Chartzoulakis, K., \& Drosos, N. (1995). Water use and yield of greenhouse grown eggplant under drip irrigation. Agricultural Water Management , 28, 113- 120. http://dx.doi.org/10.1016/0378-3774(95)01173-G 
de Wit, C. T. (1958). Transpiration and crop yields. Versl Landbouwk. Onderz. 64.6, Pudoc, Wageningen, 88 PP.

Doorenbos, J., \& Kassam, A. H. (1979). Yield response to water. FAO Irrigation And Drainage, 33, FAO, Rome, Italy. 193 p. http://dx.doi.org/10.1016/B978-0-08-025675-7.50021-2

Dudley, L. M., Ben-Gal, A., \& Shani, U. (2008). Influence of plant, soil and water on the leaching fraction. Vadose Zone Journal, 7, 420-425. http://dx.doi.org/10.2136/vzj2007.0103

Yaron D., \& Bielorai H. (1982). Linear crop response functions to salinity with a threshold salinity level.Water Resources Research 18: 101-106. http://dx.doi.org/10.1029/WR018i001p00101

Fabeiro, C., Martin, S. F., \& Juan, J. A. (2001). Yield and size of deficit irrigated potatoes. Agricultural Water Management, 48, 255-266. http://dx.doi.org/10.1016/S0378-3774(00)00129-3

Hanks, R. J. (1974). Model for predicting plant yield as influenced by water use. Agronomy Journal, 66, 660-665. http://dx.doi.org/10.2134/agronj1974.00021962006600050017x

James, L. G. (1988). Principles of farm irrigation system design. John Wiley and Sons. Inc., New York. 543 p.

Katerji, N., van Hoorn, J. W., Hamdy, A, Mastrorilli M., \& Karam F. (1998). Salinity and drought, a comparison of their effects on the relationship between yield and evapotranspiration. Agricultural Water Management,36, 45-54. http://dx.doi.org/10.1016/S0378-3774(97)00049-8

Li, F., Yan, X., Li, F., \& Guo, A. (2001). Effects of different water supply regimes on water use and yield performance of spring wheat in a simulated semi-arid environment. Agricultural Water Management, 47, 25-35. http://dx.doi.org/10.1016/S0378-3774(00)00097-4

Maas, E. V. (1984). Salt tolerance of plants. The Handbook of Plant Science in Agriculture, Christie BR (Ed.). CEC Press: Boca Raton, Fla. http://dx.doi.org/10.1061/9780784411698.ch13

Maas, E. V., \& Hoffman, G. J. (1977). Crop salt tolerance, current assessment. Journal Irrigation and Drainage. Div. ASCE, 103, 115-134. http://dx.doi.org/10.1.1.542.1486

Mannini, P., \& Gallina, D. (1996). Effects of different irrigation regimes on two tomato cultivars grown in a cold greenhouse. Irrigazione e drenaggio, 61, 64-650. http://dx.doi.org/10.5897/AJB10.2574

Mendezr, F.,J. (1987). Effect of applying different irrigation frequencies into tomato production in San Juan de Lagunillas merid state. Acta Horticulturae., 22: 383-386.

Ouda, S. A., Khalil F. A., \& Tantawy M.M. (2006). Predicting the impact of water stress on the yield of different maize hybrids. Research Journal of Agriculture and Biological Sciences 2(6): 369-374.

Oweis, T., Zhang, H., \& Pala, M. (2000). Water use efficiency of rainfed and irrigated bread wheat in a Mediterranean environment. Agronomy Journal, 92, 231-238. http://dx.doi.org/10.1007/s100870050027

Rijtema, P. E., \& Endrodi, G. (1970). Calculation of production of potatoes. Netherlands Journal of Agricultural Science, 18, 26-36.

Shani, U., \& Ben-Gal, A. (2005). Long-term response of grapevines to salinity: osmotic effects and ion toxicity. American Journal of Enology and Viticulture, 56(2), 148-154.

Shani, U., Ben-Gal, A., Tripler, E., \& Dudley, L. M. (2007). Plant response to the soil environment: an analytical model integrating yield, water, soil type, and salinity. Water Resources Researches, 43, 1-12. http://dx.doi.org/10.1029/2006WR005313

Shani, U., \& Dudley, L. M. (2001). Field studies of crop response to water and salt stress. Soil Science Society of America Journal, 65, 1522-1528. http://dx.doi.org/10.2136/sssaj2001.6551522x

Skaggs, T. H., Poss, J. A., Shouse, P. J., \& Grieve, C. M. (2006). Irrigating forage crops with saline waters: 1. Volumetric lysimeter studies. Vadose Zone Journal, 5, 815-823. http://dx.doi.org/10.2136/vz2015.06.0088

Tripler, E., Ben-Gal, A., Shani, U. (2007). Consequence of salinity and excess boron on growth, evapotranspiration and ion uptake in date palm (Phoenix dactylifera L., cv. Medjool). Plant Soil, 297, 147-155. http://dx.doi.org/10.1007/s11104-007-9328-z.

Unlukara, A., Kurunc, A., \& Kesmez. G. D. (2010). Effects of salinity on eggplant (Solanum melongena L.) growth and evapotranspiration. Irrigation And Drainage, 59, 203-214. http://dx.doi.org/10.1002/ird.453

Van Genuchten, M. T. (1983). Analyzing crop salt tolerance data: Model description and user's manual. USDA-ARS, U. S. Salinty Lab. Res. Rep. 120. U. S. Salinty Lab. Riverside, CA. 


\section{Copyrights}

Copyright for this article is retained by the author(s), with first publication rights granted to the journal.

This is an open-access article distributed under the terms and conditions of the Creative Commons Attribution license (http://creativecommons.org/licenses/by/3.0/). 